\title{
Dispersal of Sweet Pignut Hickory in a Year of Low Fruit Production, and the Influence of Predation by a Curculionid Beetle
}

\author{
Victoria L. Sork and Douglas H. Boucher \\ Department of Ecology and Evolutionary Biology, University of Michigan, \\ Ann Arbor, MI 48109, USA
}

\begin{abstract}
Summary. The rate at which fallen hickory nuts are removed from beneath the parent tree, and the effect on this rate of the seed predator Conotrachelus affinis, was studied in an oak-hickory forest in southeastern Michigan, USA, during a year in which few nuts were produced. The trees responded to Conotrachelus, which destroyed half the nut crop, by aborting inviable nuts during the summer. The seed dispersers, mostly gray squirrels, removed fallen nuts rapidly, showing the ability to distinguish viable nuts and remove them preferentially. The number of nuts removed in a week varies directly with the number available, and removal rate increases when many viable nuts are falling. The death of most seeds before dispersal, and the squirrels' efficiency at foraging on nuts and recovering them after burial, imply that successful hickory reproduction takes place only in years of heavy nut production.
\end{abstract}

\section{Introduction}

Many important forest trees of the North Temperate zone produce large seeds that are both dispersed and preyed upon by the same species of birds and mammals. The seeds of many of these species are attacked by weevils (Curculionidae), which may destroy a large portion of a tree's crop (Janzen, 1971). Thus, the fate of the seed before germination involves a three-way interaction among trees, insects, and vertebrates. This interaction system is often characterized by substantial year-to-year variation in the number of seeds produced, an example of which is the mast cycle of American beech (Fagus grandifolia) populations. One would expect the pattern and results of dispersal and predation to differ between years of high and low seed production.

This study covers the interaction of sweet pignut hickory, Carya glabra (Mill) Sweet var. odorata (Marsh) Little, its weevil predator Conotrachelus affinis Boheman, and its mammalian predator-dispersers [mostly gray squirrels, Sciurus carolinensis (Gmelin)], in a year of low seed production. The field work was 
done in the summer and fall of 1975 in an oak-hickory forest area at Haven Hill Unit of Highland State Recreation Area, Oakland County, Michigan. This area contains a second-growth stand which has not been disturbed significantly for at least 50 years; adult white, black, and red oaks (Quercus alba, Q. velutina, and $Q$. rubra) are most common, while shagbark and sweet pignut hickories (Carya ovata, C. glabra var. odorata) are of secondary importance.

Sweet pignut hickory, as well as the oaks and other hickories, produced a small fruit crop in 1975; many of the nuts were attacked by weevils. We studied the temporal patterns of nut fall and subsequent removal from midsummer through the end of the fruiting season. This study provides an example of the type of interaction through which North Temperate forests reproduce themselves.

\section{Natural History}

\section{Sweet Pignut Hickory}

Sweet pignut or red hickory has been described both as a distinct species [Carya ovalis (Wangenh.) Sarg.] and as a variety [C. glabra (Mill.) Sweet var. odorata (Marsh) Little] of pignut hickory. It is distinguished from typical C. glabra by the smaller size of its fruit, the sweet taste of the endosperm, and the complete dehiscence of the husks at maturity (Elias, 1972). We follow the nomenclature of Little $(1953,1969)$, who reduced C. ovalis to varietal status under C. glabra.

The Haven Hill study area is close to the northern limit of C. glabra, and of the genus as a whole (Nelson, 1965). This species is common in deciduous forests of eastern North America. In southeastern lower Michigan, C. glabra generally occurs in second-growth forests, associated with oaks and other hickories.

Mature trees average $15-30 \mathrm{~m}$ in height, with a diameter at breast height of 0.5 to $1 \mathrm{~m}$ (Collingwood, 1937). Production of commercial quantities of seed begins at about 30 years of age. The largest yields ( 2 bushels or more, or several thousand seeds) are produced by trees 75-200 years old (U.S. Forest Service, 1948; Nelson, 1965).

Studies of pecans [C. illinoiensis (Wangenh.) K. Koch] and mockernut hickory (C. tomentosa Nutt.) suggest that early summer growth involves mostly expansion of the fruit to full size, while during late summer the husk and shell harden and the embryo "fills" (Woodroof and Woodroof, 1927; Shen, 1973). In the fall, the mature nuts drop from the tree, with or without separating from the husk; the removal of fallen nuts by dispersers may last into December (U.S. Forest Service, 1948). Most seeds germinate the following spring, although some germination without overwintering has been observed in C. ovata (Barton, 1936).

Large seed crops are reported to occur every "1-2 years" in C. glabra (U.S. Forest Service, 1948; Nelson, 1965); however the species has not been 
shown to have a well-developed mast cycle. However, years of low fruit production, such as that described here, are probably common. There is no doubt that the trees we studied could potentially produce at least one order of magnitude more nuts than the average of 235.5 observed in 1975 .

\section{Hickory-Nut Curculio}

Conotrachelus affinis Boheman, the hickory-nut curculio, preys on the seeds of several species of Carya, including C. glabra (Schoof, 1942). Brooks (1922) and Schoof (1942) describe the biology of this beetle; Gibson (1964) discusses three related species which attack acorns. The adults emerge from hibernation in late spring, and the female begins laying eggs on the immature hickory fruits in mid-May in Ohio (Shen, 1973) and late June in West Virginia (Brooks, 1922). Eggs hatch in 5-7 days and the larvae burrow into the developing seed. The attacked fruit reportedly drop to the ground about two weeks after the larvae begin to feed. This phenomenon results in heavy seed fall in mid-July aus August, a pattern described by Shen (1973) and also found in this study. The larvae emerge from the fallen nuts approximately two weeks after drop and pupate $3-5 \mathrm{~cm}$ below the surface of the soil. The pupa stage lasts 30 days, after which the adults issue from the ground and soon go into hibernation until the following spring.

\section{Vertebrate Predator-Dispersers}

Various species of squirrels occur at Haven Hill and are probably the major removers of fallen pignut hickory nuts. We observed gray squirrels (Sciurus carolinensis Gmelin) foraging on hickory nuts in our plots and found the remains of partially eaten nuts with their toothmarks. The gray squirrel feeds primarily on hickory nuts, beechnuts, acorns, and walnuts (Brown and Yeager, 1945; Barber, 1954; Davidson, 1964), showing a preference for hickory nuts and walnuts during the fall and spring, and for acorns in the winter (Nixon et al., 1968). We have also observed red squirrels (Tamiasciurus hudsonicus Erxleben) foraging in the area, and fox squirrels (Sciurus niger Linnaeus) and flying squirrels (Glaucomys volans Linnaeus) are known to occur at Haven Hill also. U.S. Fish and Wildlife Service records (Martin etal,, 1968) show squirrels to be the major consumer of hickory nuts in the eastern U.S.

Various other animals are known to be potential seed predators but are probably less important than the squirrels. These include the Eastern chipmunk [Tamias striatus (Linn.)] which we saw in the area but was never observed feeding on hickory nuts, and small rodents such as Peromyscus leucopus (Rafinesque), which are known to occasionally collect and feed on hickory nuts (Nicholson, 1941; Howard and Evans, 1961). U.S. Fish and Wildlife Service records also list woodpeckers and grosbeaks as minor consumers. 


\section{Methods}

\section{Field Work}

The data were gathered in the oak-hickory section of forest at Haven Hill, an area of mixed beech-maple, oak-hickory, and lowland swamp forest stands. We explored the area in late July for mature Carya glabra that were producing nuts, and found six individuals with visible crops. The majority of mature C. glabra at this location produced no seed crops in 1975, so our sample included essentially all $C$. glabra nut production over an area of several hectares. We divided the samples into two groups: three trees for "collecting" (breast height diameters $=36.9 \mathrm{~cm}, 36.8 \mathrm{~cm}$, $34.7 \mathrm{~cm})$ and three for "mark-and-recapture" studies $(35.3 \mathrm{~cm}, 44.1 \mathrm{~cm}, 30.6 \mathrm{~cm})$.

All nuts under the collecting trees were collected on July 29 and divided into two groups on the basis of size. Those nuts which were mature size $(25 \mathrm{~mm}$ diameter) or nearly so probably fell during late July (see Woodroof and Woodroof, 1927; Shen, 1973); those substantially smaller than mature size presumably fell in June and early July.

On August 5, and each succeeding week through October 21, all nuts on the ground under the collecting trees were gathered. The nuts in each week's sample, as well as the two samples collected on July 29, were cut open, and each nut was classified into one of four categories: 1) those containing one or more Conotrachelus affinis larvae, 2) those with a $C$. affinis exit hole, 3) aborted and unfilled nuts that had not been attacked by $C$. affinis, and 4) apparently viable nuts which seem capable of germinating. The first two categories combined are referred to as "Infested", the third is termed "Aborted", and the fourth, "Viable". The sum of Infested and Aborted is referred to as "Inviable". While the number of nuts under the three collecting trees varied substantially, from 101 to 330 nuts per plot for the whole season, the proportions of Infested, Aborted, and Inviable nuts did not differ significantly among plots for ten of the twelve weeks. Therefore, the totals for the three collecting trees were combined.

Study plots (each $50 \mathrm{~m}^{2}, 7.1$ by $7.1 \mathrm{~m}$ ) were staked out under the centers of the canopies of the other three trees. Each plot was cleared of all Carya glabra nuts on July 29. These "mark-andrecapture" plots were censused each week through October 21, and a colored, plastic toothpick was placed in the ground $3 \mathrm{~cm}$ from each fallen nut. A different color was used each week. The number of nuts remaining beside toothpicks of each color was recorded each week for each plot. All the nuts appearing in a given week are termed a "Cohort". The weekly censuses allowed us to find how many nuts of each previously fallen Cohort had been removed from the plot or destroyed during each week.

On October 28, after all the nuts had fallen from mark-and-recapture plot trees, all the nuts remaining on the plots were collected, opened, and classified as Infested, Aborted, or Viable. The total number of nuts falling on a plot over the whole season varied from 100 to 604 . However the percent of nuts removed did not differ significantly among the three plots for 11 of the 12 weeks, so the data for the three plots were combined.

\section{Statistical Analyses}

The rates at which nuts were removed from the "mark-and-recapture" plots, were calculated in the following manner. The number of nuts on the plots each week, which had fallen since the previous week, is the variable "Newly Fallen"; the total number of nuts on the plots each week is the variable "Total". For week $t$, the number of nuts Newly Fallen minus the number of these nuts still present the following week (week $t+1$ ), gives the variable "Newly Fallen Removed $(t)$ ". Similarly, Total $(t)$ minus the number of those nuts still remaining in week $t+1$, gives "Total Removed $(t)$ ". These variables, as numbers and as percentages, are tabulated in Table 2.

A certain number of nuts must have both fallen and been removed in the period between two censuses, and thus were never seen. An estimate of this number was derived from the Per Cent Newly Fallen Removed and the number of Newly Fallen nuts actually found each week. However, since this estimate correlated highly with the variable Newly Fallen $\left(r^{2}=0.96\right)$, all analyses were done using Newly Fallen, without correction by this estimate.

The number of Newly Fallen nuts that were viable, was estimated by multiplying Per Cent Viable (Table 1, column 5) by Newly Fallen (Table 2, column 1). This variable, called Viable Newly Fallen, appears in Table 2, column 7. The disappearance rates of Viable and Inviable nuts were 
Table 1. Collecting plot samples by time of collection, all plots combined. Categories are defined in the text

\begin{tabular}{lrrrrrrr}
\hline Sample date & Viable & Aborted & Infested & $\begin{array}{l}\text { Collecting } \\
\text { plot total }\end{array}$ & $\begin{array}{c}\text { Per cent } \\
\text { viable }\end{array}$ & $\begin{array}{c}\text { Per cent } \\
\text { aborted }\end{array}$ & $\begin{array}{c}\text { Per cent } \\
\text { infested }\end{array}$ \\
\hline June-early July & 0 & 103 & 83 & 186 & 0 & 55.4 & 44.6 \\
late July & 34 & 0 & 121 & 155 & 21.9 & 0 & 78.1 \\
5 August & 12 & 24 & 98 & 134 & 9.0 & 17.9 & 73.1 \\
12 August & 4 & 16 & 25 & 45 & 8.9 & 35.5 & 55.6 \\
19 August & 9 & 10 & 19 & 38 & 23.7 & 26.3 & 50.0 \\
26 August & 33 & 18 & 6 & 57 & 57.9 & 31.6 & 10.5 \\
2 September & 15 & 21 & 0 & 36 & 41.7 & 58.3 & 0 \\
9 September & 13 & 10 & 3 & 26 & 50.0 & 38.5 & 11.5 \\
16 September & 12 & 8 & 4 & 24 & 50.0 & 33.3 & 16.7 \\
23 September & 21 & 11 & 10 & 42 & 50.0 & 26.2 & 23.8 \\
30 September & 4 & 5 & 1 & 10 & 40.0 & 50.0 & 10.0 \\
7 October & 2 & 10 & 2 & 14 & 14.3 & 71.4 & 14.3 \\
14 October & 2 & 4 & 1 & 7 & 28.6 & 57.1 & 14.3 \\
21 October & 1 & 9 & 2 & 12 & 8.3 & 75.0 & 16.7 \\
\hline Total & 162 & 249 & 375 & 786 & 20.6 & 31.7 & 47.7 \\
\hline
\end{tabular}

Table 2. Mark-and-recapture plot data by time of observation, all plots combined. Variables are defined in the text

\begin{tabular}{lccccccc}
\hline $\begin{array}{l}\text { Observation } \\
\text { date }\end{array}$ & $\begin{array}{l}\text { Newly } \\
\text { fallen }\end{array}$ & Total & $\begin{array}{l}\text { Newly } \\
\text { fallen } \\
\text { removed }\end{array}$ & $\begin{array}{l}\text { Newly } \\
\text { fallen } \\
\text { per cent } \\
\text { removed }\end{array}$ & $\begin{array}{l}\text { Total } \\
\text { removed }\end{array}$ & $\begin{array}{l}\text { Total } \\
\text { per cent } \\
\text { removed }\end{array}$ & $\begin{array}{l}\text { Viable } \\
\text { newly } \\
\text { fallen }\end{array}$ \\
\hline 5 August & 149 & 149 & 41 & 27.5 & 41 & 27.5 & 13.3 \\
12 August & 108 & 216 & 34 & 31.5 & 53 & 24.5 & 9.6 \\
19 August & 61 & 224 & 28 & 45.9 & 59 & 26.3 & 14.4 \\
26 August & 47 & 212 & 26 & 55.3 & 90 & 42.5 & 27.2 \\
2 September & 47 & 169 & 34 & 72.3 & 91 & 53.8 & 19.6 \\
9 September & 49 & 127 & 22 & 44.9 & 34 & 26.8 & 24.5 \\
16 September & 38 & 131 & 8 & 21.1 & 19 & 14.5 & 19.0 \\
23 September & 34 & 146 & 8 & 23.5 & 30 & 20.5 & 17.0 \\
30 September & 18 & 134 & 4 & 22.2 & 16 & 11.9 & 7.2 \\
7 October & 31 & 149 & 5 & 16.1 & 27 & 18.1 & 4.4 \\
14 October & 30 & 152 & 14 & 46.7 & 29 & 19.1 & 8.6 \\
21 October & 21 & 144 & 4 & 19.0 & 14 & 9.7 & 1.8 \\
\hline Total & 633 & & 228 & 36.0 & 503 & 79.5 & 166.6 \\
\hline
\end{tabular}

compared using the number of Viable Newly Fallen nuts for each Cohort and the actual number of Viable nuts remaining from that Cohort when the mark-and-recapture plot nuts were cut open on October 28. The number of Viable nuts remaining on October 28, called "Viable Unremoved", was divided by the number of Viable Newly Fallen for that Cohort to give "Viable Per Cent Unremoved"; similar calculations for Inviable nuts gave "Inviable Per Cent Unremoved". These two variables (Table 3 , columns 3 and 6) were compared using the Wilcoxon signed-ranks test. 
Table 3. Removal of viable versus inviable nuts from mark-and-recapture plots, all plots combined, by date of fall of cohort. Variables are defined in text

\begin{tabular}{cclllll}
\hline $\begin{array}{l}\text { Date of fall } \\
\text { of cohort }\end{array}$ & $\begin{array}{l}\text { Viable } \\
\text { newly } \\
\text { fallen }\end{array}$ & $\begin{array}{l}\text { Viable } \\
\text { unremoved }\end{array}$ & $\begin{array}{l}\text { Viable } \\
\text { per cent } \\
\text { unremoved }\end{array}$ & $\begin{array}{l}\text { Inviable } \\
\text { newly } \\
\text { fallen }\end{array}$ & $\begin{array}{l}\text { Inviable } \\
\text { unremoved }\end{array}$ & $\begin{array}{l}\text { Inviable } \\
\text { per cent } \\
\text { unremoved }\end{array}$ \\
\hline 5 August & 13.3 & 0 & 0 & 135.7 & 4 & 3 \\
12 August & 9.6 & 0 & 0 & 98.4 & 1 & 1 \\
19 August & 14.4 & 0 & 0 & 46.6 & 4 & 9 \\
26 August & 27.2 & 0 & 0 & 19.8 & 11 & 56 \\
2 September & 19.6 & 1 & 5 & 27.4 & 4 & 15 \\
9 September & 24.5 & 0 & 0 & 24.5 & 15 & 61 \\
16 September & 19.0 & 0 & 0 & 19.0 & 14 & 74 \\
23 September & 17.0 & 0 & 0 & 17.0 & 13 & 77 \\
30 September & 7.2 & 0 & 0 & 10.8 & 8 & 74 \\
7 October & 4.4 & 3 & 68 & 26.6 & 20 & 75 \\
14 October & 8.6 & 0 & 0 & 21.4 & 16 & 76 \\
21 October & 1.8 & 2 & 114 & 19.2 & 15 & 76 \\
\hline
\end{tabular}

Regressions among variables reported in Tables 1 and 2 were performed using Bartlett's threegroup method of Model II regression (Sokal and Rohlf, 1969, pp. 483-486). This is the appropriate technique, rather than the more commonly used Model I regression, because all these variables must be presumed to be sample measurements which include some error. The arcsine transformation was used in all regressions involving percentage variables. Disappearance curves (plots of the "Per Cent Remaining" in a cohort against its age, Fig. 4) were fitted to the logarithmic decay equation $d N / d t=-k N$. Non-linear least-squares regressions for functions of the form $Y=e^{-k t}$ were derived, combining data from all cohorts.

The values of the variables for each week do not represent independent samples, because there is temporal autocorrelation among them. Thus, one of the basic assumptions of statistics (both parametric and non-parametric) is not met, and so strictly speaking, statistical tests should not be used. We present the statistical analyses, including regression coefficients, correlation coefficients, and probability values, as descriptions of relationships rather than as tests of hypotheses. They should be interpreted as measurements of the strengths of relationships seen in the actual data, rather than as inferences concerning whether or not those relationships could be due to chance.

\section{Results}

The totals in Table 1 show that nut production for the 1975 season, which averaged 262 nuts per collecting tree, was relatively low compared to the several thousands per tree reported in the literature for mast years. Moreover, a large proportion $(80 \%)$ of the nuts either were attacked by weevil larvae $(48 \%)$ or had aborted development $(32 \%)$. There were very few viable nuts falling over the entire season ( 54 per collecting tree).

The patterns of fall for aborted and infested seeds were different from those of viable seeds (Fig. 1). Over $80 \%$ of the weevil-attacked nuts had been dropped by August 5, while a majority of the viable nuts were found from August 

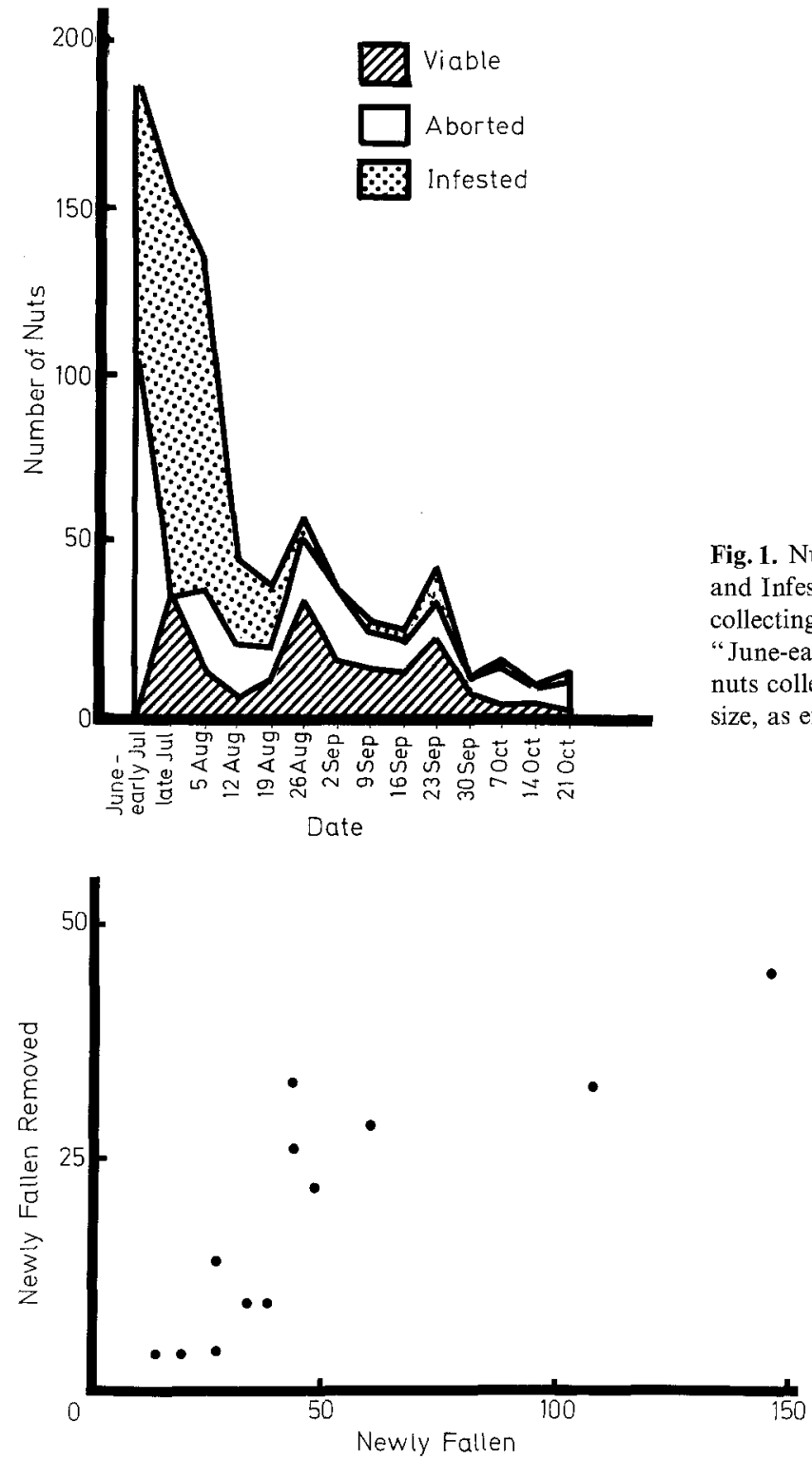

Fig. 1. Numbers of Viable, Aborted, and Infested nuts found on the three collecting plots by week. Values for "June-early July" and "late July" are nuts collected on July 29 and sorted by size, as explained in text

Fig. 2. Number of Newly Fallen nuts Removed in 1 week versus number of Newly Fallen nuts present. $r^{2}=0.68, P=0.001$

26 through September 23. Most aborted nuts fell during June, July, and August. After August 19, the number of inviable nuts that fell per week remained more or less constant (Fig. 1 and Table 1). The year's entire crop had fallen by October 21 .

Figure 2 shows that removal of newly fallen nuts is directly correlated with their number. The equation of this line is $Y=0.29 X-3.8\left(r^{2}=0.68\right.$ and $\left.P=0.001\right)$. 

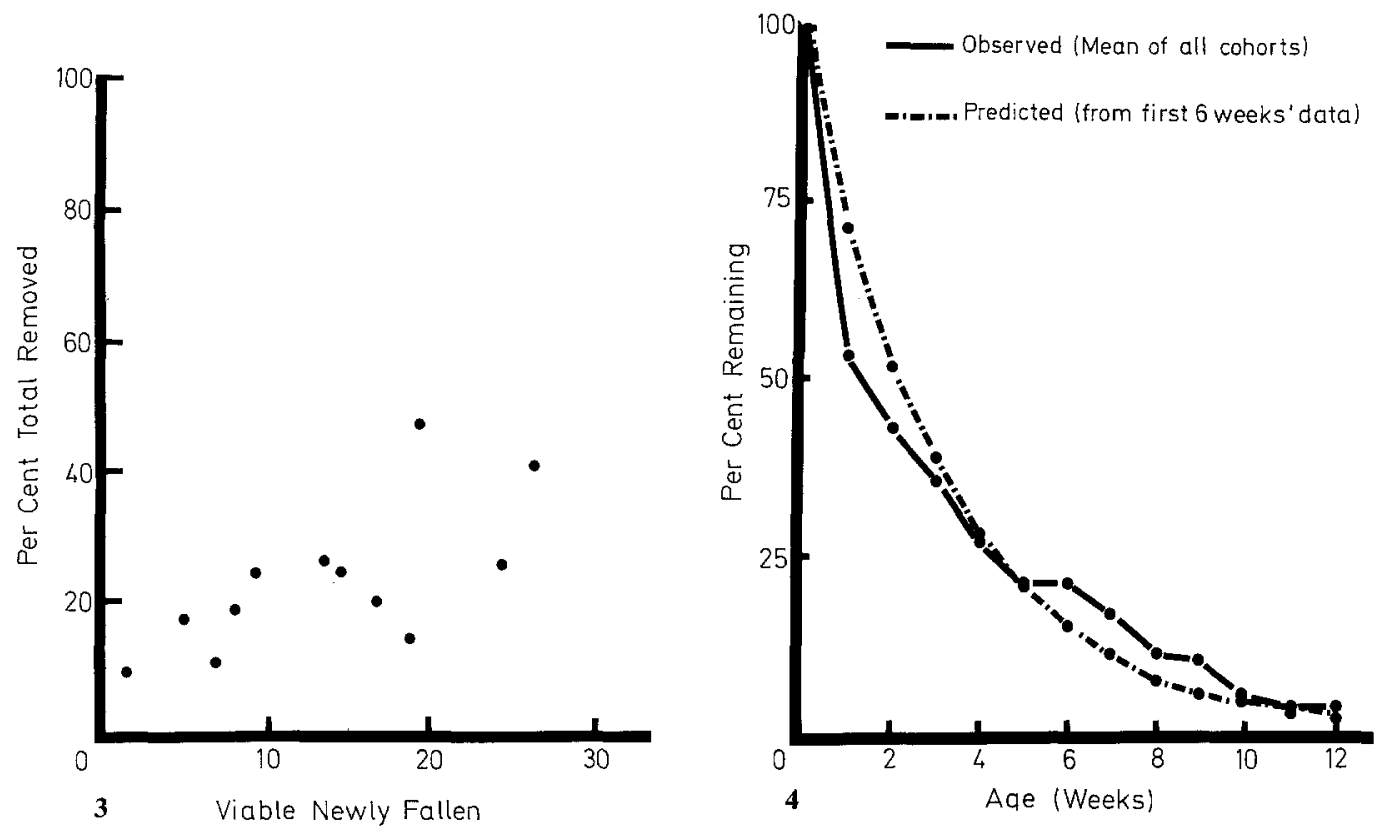

Fig. 3. Per Cent of Total number of nuts Removed in 1 week versus estimated number of Viable Newly Fallen nuts present. $r^{2}=0.45, P=0.017$

Fig. 4. Per Cent of original cohort Remaining on plot versus age of cohort, in weeks. Observed values are means of all cohorts, and Predicted values are derived from fitting the logarithmic equation to the data for the first 6 weeks a cohort is present on the plot. For correlation of Observed and Predicted, $r^{2}=0.97, P<0.001$

Thus, less than a third of the nuts newly fallen in any given week will have been removed by the following week.

The Per Cent Total Removed in a given week is correlated with the estimated number of Viable Newly Fallen nuts at the start of that week (Fig. $3 ; r^{2}=0.45$, $P=0.017)$. Per Cent Newly Fallen Removed also correlates with Viable Newly Fallen $\left(r^{2}=0.36, P=0.039\right)$. In contrast, neither Per Cent Total Removed nor Per Cent Newly Fallen Removed correlates significantly with Per Cent Viable $(P=0.32$ and $P=0.21$, respectively).

An estimate of what percentage of the nuts being removed are newly fallen can be found by regressing Newly Fallen Removed on Total Removed. The resulting equation is: $Y=0.46 X+0.07$, with $r^{2}=0.52$ and $P=0.008$. This equation suggests that nearly half of the nuts being removed are newly fallen ones.

The time course of disappearance of seeds approximates the logarithmic equation $d N / d t=-k N$ (Fig. $4 ; r^{2}=0.97, P<0.001$ ). The $k$ values for this equation do not differ significantly for the different cohorts. However, the observed values of Per Cent Remaining for latter weeks are consistently larger than what would be predicted from the removal rates in the first 6 weeks. This deviation from the logarithmic equation can be explained by the results in Table 3, which shows that by the end of the season, the nuts remaining on the ground consisted of a disproportionately large number of aborted and weevilattacked ones, and very few viable ones. The Per Cent Viable Unremoved is significantly smaller than the Per Cent Inviable Unremoved $(P<0.005$ using the Wilcoxon signed-ranks test). The deviations from the predicted curve in 
Figure 4 represent the inviable nuts from the older cohorts, which are not being removed.

The value of $\left(e^{-k(0)}-e^{-k(1)}\right)=1-1 / e^{k}$ gives an estimate of the percentage of seeds being removed within the first week after falling. With $k=0.317$ from the predicted equation in Figure 4, this estimate is $27.2 \%$, which is close to the previous estimate of $28.7 \%$. These two estimates were derived from separate but not independent parts of the data.

\section{Discussion}

The results clearly show that there is an interaction among Conotrachelus affinis, Sciurus carolinensis, and Carya glabra var. odorata. The data are not sufficient to analyze the coevolution of these three species (see Smith, 1970), but they do illustrate the factors affecting the reproductive success of Carya glabra within ecological time. The dynamics of this system do not always operate in the manner of this year; nonetheless, the observed results can serve as a general model for this system.

The success of a tree in producing seedlings depends heavily on the dispersal of its seeds. For large-seeded species having vertebrate predator-dispersers, this will depend greatly on the trees' ability to make large numbers of seeds available to the dispersers; it will also be affected by the temporal pattern of availability of seeds. The number of seeds available to dispersers depends on the number produced and the proportion that develop fully and escape insect predation. Because all these factors affect the foraging behavior of the dispersers, their interaction is an important component of the dispersal process.

Several workers (Downs, 1944; Downs and McQuilken, 1944; Beal, 1952; Christisen, 1955; Gashwiler, 1970; Griffin, 1971; Gibson, 1972) have found greater proportionate loss of seeds to insect and vertebrate predators in years of low seed production. However, Gibson (1971) found the reverse pattern, and in Dalke's data (1953) this holds only for all tree species considered together, not for individual species. Thus, in years of low seed production, very few seeds are available for dispersal. In our study, $50 \%$ of the crop was destroyed by weevils, and many of the seeds failed to develop correctly for unknown reasons. Thus only $20 \%$ of the crop was left for dispersal and possible germination.

Most of the inviable nuts were aborted in June, July, and early August. This pattern, also observed by Brooks (1922), suggest that the tree can detect changes in the development of fruits and respond by dropping some seeds early. As a result, most of the inviable nuts fall in the summer and most of the viable nuts in the fall.

Removal of nuts by squirrels is, to a first approximation, proportional to input of nuts. The fit to the logarithmic equation $d N / d t=-k N$ confirms this result. Therefore, squirrel foraging activity varies directly with the number of nuts available. The logarithmic equation has also been found to fit removal of acorns (Fox, 1974) and seeds of the tropical palm Socratea durrissima (Oerst.) Wendl. (Vandermeer, in preparation). The logarithmic pattern indicates a constant probability of removal per nut per week. In our case, the probability 
is very high, resulting in very rapid nut removal. Nearly one-third of the seeds were removed in the first week after they fell, and $80 \%$ were gone after five weeks on the ground.

A more detailed analysis indicates that the squirrels can distinguish between viable and inviable nuts, showing preference for the viable ones. There is a strong correlation between the percentage of newly fallen nuts removed and the number of viable newly fallen nuts, as well as between the total percentage removal of nuts and the number of viable newly fallen nuts. Thus, a nut's probability of removal increases when there are many viable ones present. The lack of correlation between the percentage removal and the percentage of viable newly fallen nuts indicates that the squirrels are responding to the number of good nuts, not their proportion.

The outcome of the squirrels' efficient removal of viable nuts is that essentially all the nuts remaining under the tree at the end of autumn are inviable. Seedling production depends on those nuts that are removed but not consumed immediately. Many of these nuts are buried by the squirrels, but most will be recovered and consumed later, especially in the spring (Cahalane, 1932; Nixon et al., 1968; Brown and Yeager, 1945).

Squirrels show a preference for hickory nuts and walnuts in the fall and spring and for acorns in the winter (Nixon et al., 1968). Hickory nuts and walnuts have higher protein and fat content than acorns (Wainilo and Forbes, 1941), but they also have thicker shells and husks which require more time for feeding (Smith and Follmer, 1972). Smith and Follmer explain the seasonal preferences as follows: hickory nuts and walnuts supply energy and nutrients for the foraging season and the reproductive season, while during the winter, the thin-shelled acorns allow the squirrels to minimize time outside the nest. In years of low seed production such as this one, the squirrels are likely to eat the entire crop.

The result of animal-seed interactions in low-yield years is that probably very little tree reproduction takes place in these years. This occurs even in the face of tree responses (i.e. abortion of inviable seeds in summer) and squirrel removal efficiency, factors which would be an aid to reproduction in high-yield years. As with other mast-fruiting trees (Janzen, 1971, 1974; Formosof, 1933), reproduction of Carya glabra seems to depend on large seed crops.

Acknowledgements. We thank Highland State Recreation Area for permission to work at Haven Hill, Anita Boucher, Isabell Hull, and Gayle Rubin for their assistance in the field, Dan Fox and Ken Guire for help with the statistical analyses, and Dave Foltz, Lester Gibson, Dan Janzen, Phil Myers, Marlene Palmer, Deborah Rabinowitz, John Vandermeer, and the Biological Sciences Graduate Student Seminar for helpful comments and suggestions. Doug Boucher was supported by a National Science Foundation Graduate Fellowship.

\section{References}

Barber, H.L.: Gray and fox squirrel food habit investigations. Proc. Southeastern Assoc. Game and Fish Commissioners 8, 92-94 (1954)

Barton, L.V.: Seedling production in Carya ovata (Mill.) K. Koch, Juglans cinerea L., and Juglans nigra L. Contr. Boyce Thompson Inst. 8, 1-5 (1936)

Beal, J.A.: The more important insects of Duke Forest and the Piedmont Plateau. Duke Univ. School Forestry Bull. 44, 18-24 (1952) 
Brooks, F.E.: Curculios that attack the young fruits and shoots of walnut and hickory. U.S. Dept. Agriculture Bull. 1066, 16 pp. (1922)

Brown, L.G., Yeager, L.E.: Fox squirrels and gray squirrels in Illinois. Ill. Nat. Hist. Survey Bull. 23, 448-536 (1945)

Cahalane, V.H.: Caching and recovery of food by the western fox squirrel. J. Wildl. Mgmt. 6, $338-352$ (1932)

Christisen, D.M.: Yield of seed by oak in the Missouri Ozarks. J. Forestry 53, 439-441 (1955)

Collingwood, G.H. : Pignut hickory, Hicoria glabra. Amer. Forests 43, 546-547 (1937)

Dalke, P.D.: Yield of seeds and mast in second growth hardwood forest, southcentral Missouri. J. Wildl. Mgmt. 17, 378-386 (1953)

Davison, V.C.: Selection of foods by gray squirrels. J. Wildl. Mgmt. 28, 346-352 (1964)

Downs, A.A.: Estimating acorn crops for wildlife in the southern Appalachians. J. Wildl. Mgmt. 8, 339-340 (1944)

Downs, A.A., McQuilken, W.E. : Seed production of southern Appalachian oaks. J. Forestry 42, 913-920 (1944)

Elias, T.S.: The genera of Juglandaceae in the southeastern U.S. J. Arnold Arboretum 53, 26-51 (1972)

Formosof, A.N.: The crop of cedar nuts, invasions into Europe of the Siberian nutcracker (Nucifraga caryoctactes macrorhynchus Brehm) and fluctuations in numbers of the squirrel (Sciurus vulgaris L.). J. anim. Ecol. 2, 70-81 (1933)

Fox, J.F.: Coevolution of white oak and its seed predators. Ph.D. thesis, Univ. of Chicago, $90 \mathrm{pp}$. (1974)

Gashwiler, J.S.: Further study of conifer seed survival in a western Oregon clearcut. Ecology 51, 849-854 (1970)

Gibson, L.P.: Biology and life history of acorn-infesting weevils of the genus Conotrachelus (Coleoptera: Curculionidae). Ann. ent. Soc. Amer. 57, 521-526 (1964)

Gibson, L.P.: Insects of bur oak acorns. Ann. ent. Soc. Amer. 64, 232-234 (1971)

Gibson, L.P.: Insects that damage white oak acorns. U.S. Forest Service Research Paper NE-220, 7 pp. (1972)

Griffin, J.R.: Oak regeneration in the upper Carmel Valley, California. Ecology 52, 862-868 (1971)

Janzen, D.H.: Seed predation by animals. Ann. Rev. Ecol. Syst. 2, 465-492 (1971)

Janzen, D.H.: Tropical blackwater rivers, animals, and mast fruiting by the Dipterocarpaceae. Biotropica 6, 69-103 (1974)

Little, E.L.: Check list of native and naturalized trees of the United States (including Alaska). U.S. Dept. Agriculture Hndbk. 41 (1953)

Little, E.L. : Two varietal transfers in Carya (Hickory). Phytologia 19, 186-190 (1969)

Martin, A.C., Zim, H.S., Nelson, A.L.: American wildlife and plants: A guide to wildlife food habits. New York: Dover 1968

Nelson, T.C.: Silvical characteristics of the commercial hickories. U.S. Forest Service Southeastern Forest Experiment Station, Hickory Task Force Report 10, 16 pp. (1965)

Nixon, C.M., Worley, D.M., McClain, M.W.: Food habits of squirrels in southeastern Ohio. J. Wildl. Mgmt. 32, 294-305 (1968)

Schoof, H.F.: The genus Conotrachelus DeJean (Coleoptera, Curculionidae) in the north central United States. Illinois biol. Monographs 19, 1-170 (1942)

Shen, A.P.: Interactions among mockernut hickory (Carya tomentosa, Juglandaceae) and its seed predators (Conotrachelus affinis and Curculio caryae, Curculionidae, Coleoptera). M.S. thesis, Ohio State University (1973)

Smith, C.C.: The coevolution of pine squirrels (Tamiasciurus) and conifers. Ecol. Monogr. 40, 349-371 (1970)

Smith, C.C., Follmer, D.: Food preferences of squirrels. Ecology 53, 82-91 (1972)

Sokal, R.R., Rohlf, F.J.: Biometry. San Francisco: Freeman 1969

U.S. Forest Service: Woody-plant seed manual. U.S. Dept. Agriculture Misc. Publ. 654 (1948)

Wainilo, W., Forbes, E.B.: Chemical composition of forest fruits and nuts from Pennsylvania. J. agric. Res. 62, 627-635 (1941)

Woodroof, J.G., Woodroof, N.C.: The development of the pecan nut from flowering to maturity. J. agric. Res. 34, 1049-1063 (1927)

Received January 5, 1977 